Chair for Management Science and Energy Economics University of Duisburg-Essen

EWL Working Paper No. 07/2011

\title{
PROSPECTS FOR PUMPED-HYDRO STORAGE IN GERMANY
}

by

Bjarne Steffen

December 2011 


\title{
Prospects for pumped-hydro storage in Germany
}

\author{
by Bjarne Steffen
}

\begin{abstract}
After a period of hibernation, the development of pumped-hydro storage plants in Germany regains momentum. Motivated by an ever increasing share of intermittent renewable generation, a variety of energy players considers new projects, which could increase the available capacity by up to $60 \%$ until the end of the decade. This paper analyzes the current development and evaluates the revenue potential as well as possible barriers. Overall, the prospects for new pumped-hydro storage plants have improved, even though profitability remains a major challenge.
\end{abstract}

Keywords: pumped-hydro energy storage, power plant investment, Germany JEL-Classification: L94, Q42, Q48

\section{DIPL.-VOLKSW. BJARNE STEFFEN}

Chair for Management Sciences and Energy Economics,

University of Duisburg-Essen (Campus Essen)

Universitätsstr. 11, 45117 Essen

++49 - (0)2 01 / 183-2399

www.ewl.wiwi.uni-due.de

steffen.bjarne@bcg.com

The authors are solely responsible for the contents which do not necessarily represent the opinion of the Chair for Management Sciences and Energy Economics. 


\section{Introduction}

With increasing shares of power generation from renewable energy sources, the possibility to balance fluctuating wind and solar power gains in importance. Both on the European and national levels, energy policy therefore strives to increase the number of storage plants (EC, 2007; BMWi, 2010). This is especially true for Germany which decided to quickly phase-out nuclear generation following the Fukushima accident. The gap in electricity supply shall be closed by renewable energy sources to the maximum extent possible, which places the question of additional storage plants high on the policy agenda. As Germany is Europe's largest power market and is highly interconnected with other countries, the development of storage capacity in Germany has an impact well beyond its borders.

The main established technology for large-scale electricity storage is pumped-hydro storage (PHS), with plants consisting of two water reservoirs in different altitudes connected by a penstock. During off-peak periods, pumps are used to move water to the upper basin to be able to release it to the lower basin during peak times, driving turbines in the same way as in conventional hydro plants.

PHS has a long tradition in Germany, with the first sites dating back to the 1920s. As shows the exhibition of cumulated capacity in fig. 1, large plants went into operation in the 1970s and 1980s; since then, however, the capacity growth came to a halt. The only new plant after 1990 has been the 1.1 GW Goldisthal plant which went online in 2003. This plant had been planned since 1975, but could not be realized until the German reunification. Today, the gross capacity adds up to $7.6 \mathrm{GW}$ (including Vianden ${ }^{1}$ ), which amounted to $4.9 \%$ of total power generation capacity in 2010 .

Significant PHS capacities also exist in other European countries. A detailed review of new PHS projects across Europe has been provided by Deane et al. (2010). ${ }^{2}$ While many new sites and extensions are planned in Austria and Switzerland, the authors list only one project in Germany (the 1.4 GW Atdorf plant). This is in line with a general belief that the potential for PHS plants in Germany is largely exhausted due to the topographic conditions (VDE, 2009; SRU, 2011).

Since 2010, however, a surge of projects could be observed, with the announcement of two extension and ten new build proposals. This paper therefore reviews the development drawing on documents from the official spatial planning procedures as well as company announcements and press reports. We show that up to $4.7 \mathrm{GW}$ additional PHS capacity could be realized in the coming years, with investment costs comparable to projects in other European countries. Most projects require the construction of at least one new reservoir, and compliance with nature conversation laws as well as local resistance are hurdles these projects have to clear. As it is generally the case for generation capacities in Germany, the profitability of PHS projects is subject to uncertainty-with growing political support in light of the transformation towards a more sustainable power system, however, the prospects for new PHS plants in Germany have improved, and it is quite possible that considerable capacity will be completed until the end of the decade.

The next section describes the planned PHS plants on a project level, while an overall analysis

\footnotetext{
${ }^{1}$ The Vianden plant is located in Luxembourg. As the lower basin is partly in Germany and the plant is operated according to the needs in the adjacent German grid control area, however, it is typically counted as storage capacity available for the German grid (Giesecke et al., 2009), which is why we include it in this paper.

${ }^{2}$ Yang and Jackson (2011) presented a similar study for the US.
} 


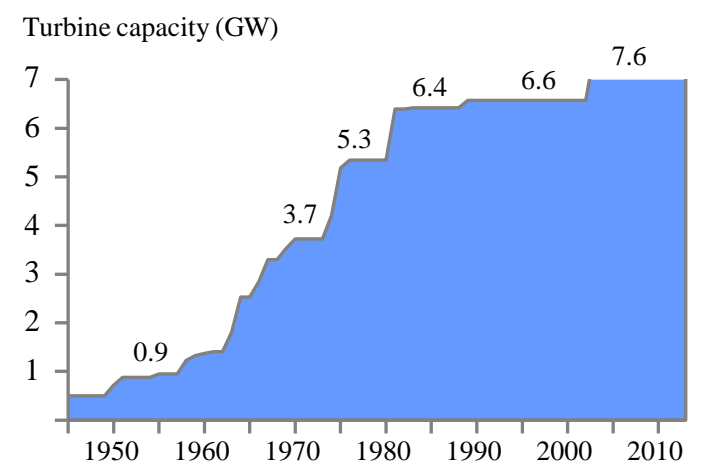

Figure 1: Development of PHS capacity in Germany (incl. Vianden)

of trends and barriers is provided in sections 3 and 4 . Finally, section 5 summarizes the findings and concludes.

\section{Overview of PHS projects}

PHS projects have been proposed all across Germany. Fig. 2 provides a geographic overview of the plants: Distributed over lower mountain ranges, they are situated both close to existing plants and in new locations. Two criteria are used to qualify the projects described in detail:

- The project has been announced by an energy company that plans to build and operate the plant (this excludes proposals which are supported by political actors or scientists only);

- the location is clearly defined, and the spatial planning procedure (German Raumordnungsverfahren) has started or is scheduled to start in 2012.

In the following, motivation and ownership as well as the projected timeline are described for each project, chronologically in the order of expected completion dates. Technical parameters for all plants are summarized in table 1.

\section{$2.1 \quad$ Vianden M 11}

Europe's largest PHS plant is situated at Vianden on the border Luxembourg-Germany and has been extended in several steps up to its current turbine capacity of 1,096 MW. Since 2006, the operator SEO S.A. (co-owned by the state of Luxembourg and German RWE AG) has planned the most recent extension project called "M 11" (machine 11) which adds $200 \mathrm{MW}$ turbine capacity in a new underground cavern while at the same time the reservoir dams are extended. The new machines significantly increase the reserve power that can be provided to the grid area, which is cited as a major motivation for the project. Civil works started in 2010; completion is planned by 2013 (SEO, 2010, 2011a,b). 


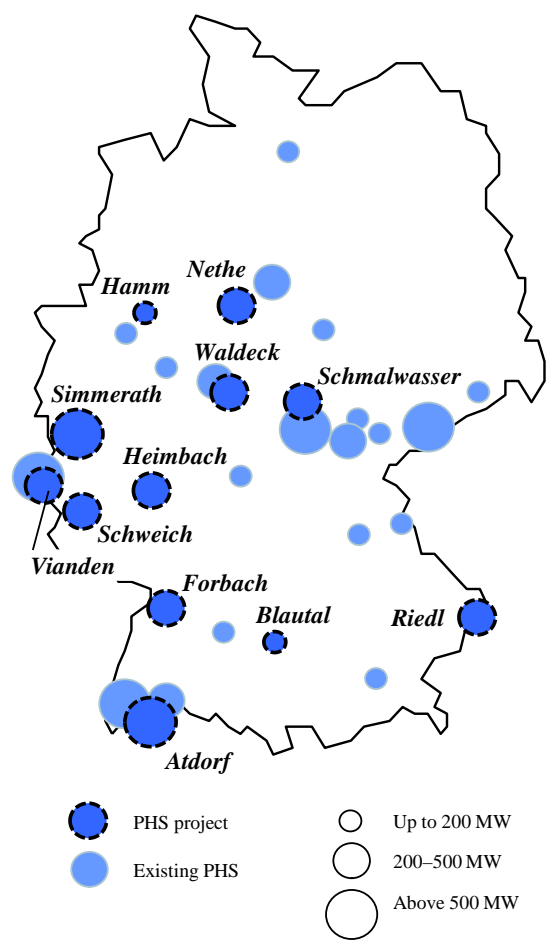

Figure 2: Map of PHS projects in Germany

\section{$2.2 \quad$ Ruhr spoil tip plants}

While the Vianden project is just another extension of a well-established plant complex, a new setup is proposed in the Ruhr area. In 2010, RWE AG subsidiary Innogy GmbH signed a letter of intent with RAG Montan Immobilien $G m b H$, the administrator of areas formerly used by hard coal mining. The companies envisage to build plant parks consisting of PHS capacities and on-site windmills, taking advantage of 50-100 m high spoil tips. The combination of wind power and PHS would allow a controllable provision of electricity from renewable energy sources. Given that the reservoirs would be built on formerly industrial areas, few environmental concerns are expected. A 15-20 MW pilot plant near the city of Hamm could be completed by 2014, if the commercial assessment proves advantageous (RAG, 2010, 2011; WAZ, 2010).

\subsection{Blautal plant}

The intent to build the Blautal plant west of Ulm has been announced already much earlier, in 2005. The regional utility Stadtwerke Ulm/Neu-Ulm GmbH emphasizes the goal to balance demand peaks in the region and to reduce dependency on expensive peak power purchases. The spatial planning procedure for the lower basin and a turbine house on the area of a quarry have been finished in 2009. For the upper reservoir, though, six options have been evaluated unsuccessfully, opposed by involved parties for landscape architecture and environmental reasons. In 2011, the project re-gained momentum with the decision to pursue an upper reservoir near the town Markbronn; a separate spatial planning procedure is scheduled to start in 2012. The ad- 
justed plant project would offer $60 \mathrm{MW}$ turbine capacity after a construction period of 3-4 years (Öko-Institut e.V., 2011; SWU, 2006, 2010; Regierungspräsidium Tübingen, 2009).

\subsection{Waldeck 2 plus}

In 2010, E.ON Energie $A G$ announced an extension to its 600 MW PHS plant group on the Hessian Edersee lake, referring to the general need to extent storage capacity in light of renewable energy sources. Additional pump-turbines are planned to add $300 \mathrm{MW}$ capacity to one of the upper reservoirs which will be extended at the same time. As the new penstock and machines are realized in an underground cavern, environmental impact is expected to be limited to the construction period. Local authorities as well as conservationists look upon the project favorably, which is expected to go online in 2016 (E.ON Wasserkraft, 2010, 2011; FAZ, 2011).

\subsection{Schweich plant}

The local utility of the Mosel city Trier, Stadtwerke Trier GmbH, announced a new build PHS project in April 2011. The region is characterized by significant capacity in renewable energy sources, and the utility aims to balance their intermittent demand regionally, to allow local consumers to use a higher share of the power from renewable plants in their region. Therefore, two artificial reservoirs in the Schweich county are proposed, offering a capacity of 200-500, likely 300 MW. Regional and local authorities are asked to share the investment costs. If permissions are granted by 2012, the plant could go online in 2015-17 (SWT, 2011a,b).

\subsection{Riedl plant}

Building on earlier plans from the 1970s, another new build project has been announced in 2010 near the Lower Bavaria city Passau, brought forward by the hydro plant operator Donaukraftwerk Jochenstein (DKJ) AG (a joint venture of Austrian Verbund $A G$ and E.ON Energie $A G$-dominated $R M D A G)$. The plant shall contribute to the security of power supply in Bavaria and Austria in light of increasing fluctuating energy sources; the project developers also emphasize a stimulus for the regional economy. To achieve a capacity of $300 \mathrm{MW}$, an artificial reservoir is planned near the town Riedl at $300 \mathrm{~m}$ height above the river Danube that serves as lower basin. The penstock is planned underground, limiting the impact on the hillside which is a conservation area under the Habitats directive. The spatial planning procedure was successfully finished in August 2011; the final permission procedure shall start in the beginning of 2012. While local and environmental pressure groups oppose the project, it is supported by the county and the district. Construction is planned 2014-2018 (DKJ, 2010, 2011a,b; ifo institute, University of Passau, 2010).

\subsection{Forbach new plant group}

In the northern Black Forest, a new plant group is brought forward by $E n B W A G$. Since the 1920, different plants linked to the Schwarzenbach dam are operated with a total PHS capacity of 70 MW. In 2010, the operator published a feasibility study for two extension projects adding another 200 MW. First, an equalizing reservoir shall be extended by an underground cavern, using the main dam as upper reservoir. Second, the main dam itself is suggested to serve as lower basin 


\begin{tabular}{lccccc}
\hline Plant project & State $^{a}$ & $\begin{array}{c}\text { Head } \\
(\mathrm{m})\end{array}$ & $\begin{array}{c}\text { Capacity } \\
(\mathrm{MW})\end{array}$ & $\begin{array}{c}\text { Costs } \\
(€ \mathrm{M})\end{array}$ & $\begin{array}{c}\text { Planned } \\
\text { completion }\end{array}$ \\
\hline Vianden M 11 & $($ Lux.) & 280 & 200 & 155 & 2013 \\
Ruhr spoil tip plants & NW & $50-100$ & $15 / 200^{b}$ & n.a. & $2014 /$ n.a. $^{b}$ \\
Blautal (Ulm) & BW & 170 & 60 & 60 & $2015-2016$ \\
Waldeck 2 plus & HE & 360 & 300 & 250 & 2016 \\
Schweich (Trier) & RP & 200 & 300 & $300-400$ & $2015-2017$ \\
Riedl & BY & 350 & 300 & 350 & 2018 \\
Forbach & BW & $320-360$ & 200 & 250 & 2018 \\
Atdorf & BW & 600 & 1400 & 1200 & 2019 \\
Heimbach (Mainz) & RP & 500 & $400-600$ & $500-700$ & 2019 \\
Simmerath & NW & 240 & 640 & 700 & 2019 \\
Nethe (Höxter) & NW & 220 & 390 & $500+$ & 2019 \\
Schmalwasser & TH & $200-300$ & 400 & $500+$ & 2019 \\
\hline
\end{tabular}

\footnotetext{
${ }^{a} \mathrm{BW}=$ Baden-Wuerttemberg, $\mathrm{BY}=$ Bavaria, $\mathrm{HE}=$ Hesse, Lux.= Luxembourg, $\mathrm{NW}=$ North Rhine-West phalia, $\mathrm{RP}=$ Rhineland-Palatinate, $\mathrm{TH}=$ Thuringia

${ }^{b}$ Pilot plant/all planned plants
}

Table 1: Parameters of proposed PHS plants

in conjunction with a new uphill reservoir. In the spatial planning procedure, the integration of renewable energy sources and the provision of grid services have been mentioned as motivation for the project. So far, local acceptance is high; the construction could take place 2014-2018 (EnBW, 2010, 2011; StN, 2011; Planungsausschuss RV Mittlerer Oberrhein, 2010).

\subsection{Atdorf plant}

With a planned capacity of 1,400 MW, the new build project near the Black Forest town Atdorf is the largest PHS project in Germany and has been intensively discussed since its initial announcement in 2008. The Schluchseewerk AG, co-owned by RWE $A G$ and EnBW AG, operates two other PHS plant groups in the region. The project includes an artificial upper reservoir as well as a dam to create a lower basin in a valley about $10 \mathrm{~km}$ south. Underground structures are planned for penstock and machines; while the proposed reservoirs are not in areas protected under the Habitats directive, such areas might be affected during construction. Extensive evaluations of the public interest have therefore been commissioned to Dena and Fraunhofer IWES institutes (Dena, 2010; Fraunhofer IWES, 2010); these studies are widely cited to underline the need of additional storage capacity in Germany. The project is opposed by environmental organizations and a local initiative fearing a loss of tourists. However, the respective municipalities agreed to the project in exchange for a new drinking water supply system. The spatial planning procedure was successfully finished in December 2010; final permissions shall be attained by 2013, with the construction period being planned 2014-2019 (Regierungspräsidium Freiburg, 2011; Schluchseewerk, 2010; Die Zeit, 2010a).

\subsection{Heimbach plant}

In April 2011, the Rhineland-Palatinate utility Stadtwerke Mainz AG announced a 400-600 MW PHS project as part of its effort to improve the exploitation of renewable energy sources. The 
upper reservoir shall be situated on top of the Franzosenkopf mountain near the Middle Rhine town Niederheimbach, using the river as lower basin. Planning permissions are expected until 2015, which would allow a completion by 2019. First discussions with local authorities and a town hall meeting did not raise major concerns - conformity with the Habitats Directive is seen as most important challenge, as large parts of the construction would be situated in a protected area (SW Mainz, 2011a,b; AZ Bingen, 2011; SGD Süd, 2011).

\subsection{Simmerath plant}

The joint venture of regional utilities, Trianel $G m b H$, announced the intention to build two PHS plants in North Rhine-Westphalia in July 2011, motivated by increasing shares or renewable energy sources. The first one shall be situated in Simmerath near the city of Aachen, where the area of a wind farm offers convenient conditions for the upper reservoir; the nearby Rur dam would serve as lower reservoir. Plans include a visitor tunnel to allow touristic visits of the $640 \mathrm{MW}$ turbines. The project is unanimously supported by the municipal council and the state government; also a town hall meeting did not raise any strictly opposing remarks. Consequently, the spatial planning procedure is scheduled to start in 2012; the construction period is planned 2016-2019 (Trianel, 2011a; Aachener Z., 2011a; Trianel, 2011d).

\subsection{Nethe plant}

The second PHS project announced by Trianel $G m b H$ is situated in eastern Westphalia close to the city of Höxter. Two artificial reservoirs with an underground penstock next to the river Nethe are suggested, providing $390 \mathrm{MW}$ capacity. The proposed basin locations are out of view of residential areas, also no nature conservation areas are affected by the project; a flood control concept is perceived as only challenge during the spatial planning procedure. As for the other Trianel project, completion is planned by 2019 (Trianel, 2011b,c; Beverunger R., 2011).

\subsection{Schmalwasser plant}

Adding to the other two project, Trianel GmbH announced a third project in October 2011, together with the state government of Thuringia. The existing Schmalwasser dam (formerly used as drinking water storage) is planned to serve as lower basin, supplemented by a new upper reservoir and an underground penstock. A turbine capacity of $400 \mathrm{MW}$ could go online in 2019 (TMWAT, 2011b).

\subsection{Further concepts}

In addition to the projects described above, a number of studies suggest PHS facilities in further locations. In July 2011, Stadtwerke Düsseldorf and Enervie AG signed a memorandum of understanding to build a 200-400 MW PHS plant in the Sauerland mountain range by 2018, five possible locations are currently being evaluated (Enervie, 2011; Westfalenpost, 2011). Also Trianel GmbH is evaluating additional locations (Aachener Z., 2011a). Vattenfall Europe AG, the operator of the northern 120 MW Geesthacht PHS plant, requested the right to double the capacity by means of a second upper reservoir during a recent update of the land development plan (Bergedorfer Z., 
2011). In total, an internal study of $R W E A G$ identified up to 20 possible PHS sites in western and southwestern Germany (likely overlapping with some of the projects described above) (Vennemann et al., 2011). ${ }^{3}$

Further projects are proclaimed by political actors and scientists. The state of Thuringia published a registry of 13 possible locations in the state (TMWAT, 2011a); also the state of North Rhine-Westphalia commissioned a study to register PHS-suitable locations (Aachener Z., 2011b). The regional administration in the Harz mountain range evaluates an underground PHS setup which would use abandoned mining shafts (IZH, 2011); another possible location for underground PHS plants is the Ruhr area (Die Zeit, 2010b). Furthermore, scientists investigate an addition of pump-turbines to locks and boat lifts on federal waterways, which would allow to exploit the height profile of German channels for PHS purposes (Schomerus and Degenhart, 2011).

To date, all these projects are too early in the planning stage to be included in our analysis-they show, though, that ample additional locations are in principle available.

\section{Common trends}

Besides all site-specific peculiarities, the recent PHS development constitutes a general trend in the German power market. The announced projects share a number of joint characteristics, that are evaluated in this section.

\subsection{Magnitude and drivers of capacity growth}

The total PHS capacity that could be added is summarized in fig. 3; it sums up to $4.71 \mathrm{GW}$. If all projects would be realized as planned, this related to an increase in overall capacity of $60 \%$. The announcement of projects with such a size within a short time frame is surprising, especially given the long hibernation of PHS development in Germany. It reflects the political intentions to transform energy systems towards a more sustainable setup, that motivates both regional utilities and energy groups to look for profitable investments related to renewable energy sources. Consequently, the integration of intermittent wind and solar power is cited almost in unison as the major driver to build storage capacity; in the case of the Ruhr spoil tips project, even the on-site combination of windmills and PHS is planned.

Furthermore, the provision of grid services like reserve power is part of many plant projects, which is also related to the scarcity of such services if thermal capacity is replaced by renewable energy sources to a large extent. Among the regional utilities pursuing PHS projects, an increased autarky with less dependence on power procurement from outside the region adds to the arguments to build a PHS plant.

\subsection{Setup and technology}

All projects described above are pure PHS plants, as opposed to 'pump-back' setups where the pumping installation adds to a conventional hydro storage plant (which dominate projects in the

\footnotetext{
${ }^{3}$ Another 100-200 MW PHS plant has also been proposed near the town Einöden in southeast Germany. RWEsubsidiary Bayerische Elektrizitätswerke withdrew from the project in 2010, though, and other investors have not been found yet (IBW, 2011).
} 


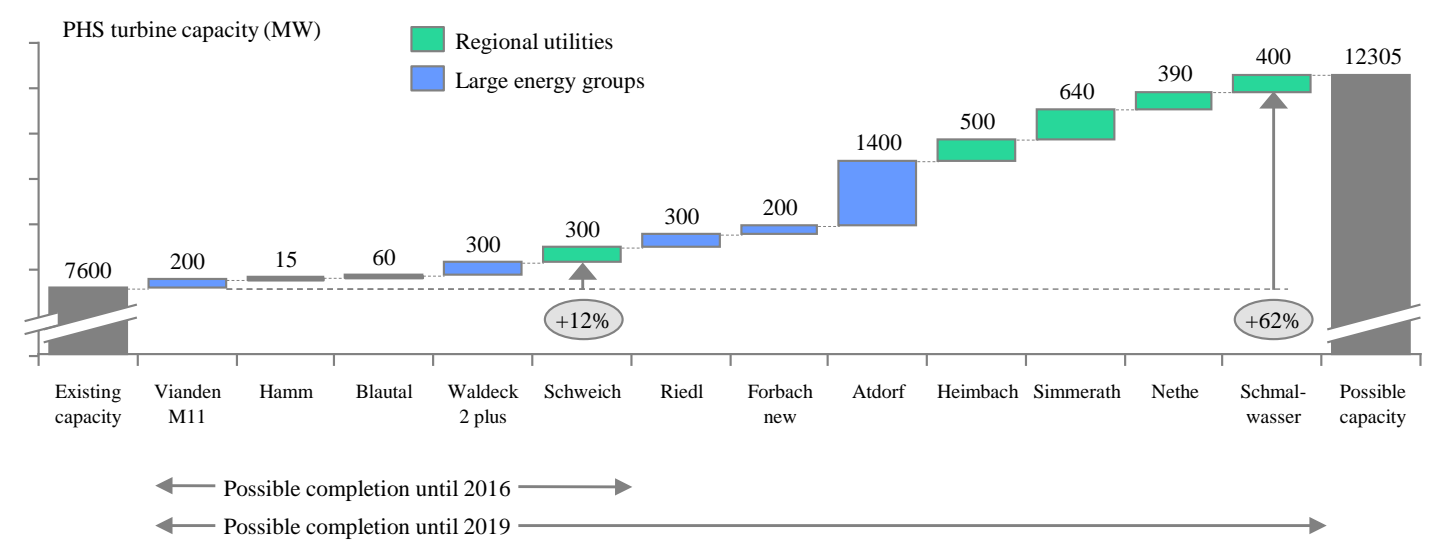

Figure 3: Overview of planned PHS capacity

rest of Europe (Deane et al., 2010)). Seven out of twelve projects are planned independently from existing reservoirs - a clear sign that attractive new build sites are available. Fig. 4 shows that beyond the extensions in Vianden and Waldeck, all plants will have a new upper reservoir. Instead of a lower basin, two projects rely on a river as lower reservoir - this setup (to date unusual in Germany) allows the construction of PHS in narrow valleys where no space for a lower reservoir is available. Another innovative approach is the use of spoil tips as planned in the Ruhr area, where the comparative low head is likely compensated by lower construction costs. Six out of twelve projects (decided to locate machines in an underground cavern, reducing interference with nature and landscape as well as noise emissions during operation.

\subsection{Investment costs}

The announced investment cost estimates per $\mathrm{kW}$ turbine capacity are shown in fig. 5. The weighed average across projects is $€ / \mathrm{kW} 1,048$, which is $9 \%$ above the European projects surveyed by Deane et al. (2010) (weighted average of $€ / \mathrm{kW} 961$ ). Notably, this is well below the assumption in the scenarios provided by SRU (2011) of $€ / \mathrm{kW} 1,600$. By that, the PHS projects come with significant lower upfront investments than hard coal plants (in the range of $€ / \mathrm{kW} 1,400$ ), while both OCGT and CCGT gas plants require still less investment (in the range of $€ / \mathrm{kW} 450$ and $€ / \mathrm{kW} 600$, respectively). Hence, PHS will take a mid-merit role in an efficient generation portfolio (Steffen and Weber, 2011).

Not surprisingly, PHS extension projects require lower investments than greenfield projects. For the latter, a weighted OLS regression exhibits a cost digression with larger plant sizes (see table 2). The effect is largely driven by the high leverage (.83) of the $1.4 \mathrm{GW}$ Atdorf plant, though, and no significant cost digression can be observed among the other projects - site-specific conditions seem to be more important than size effects. 


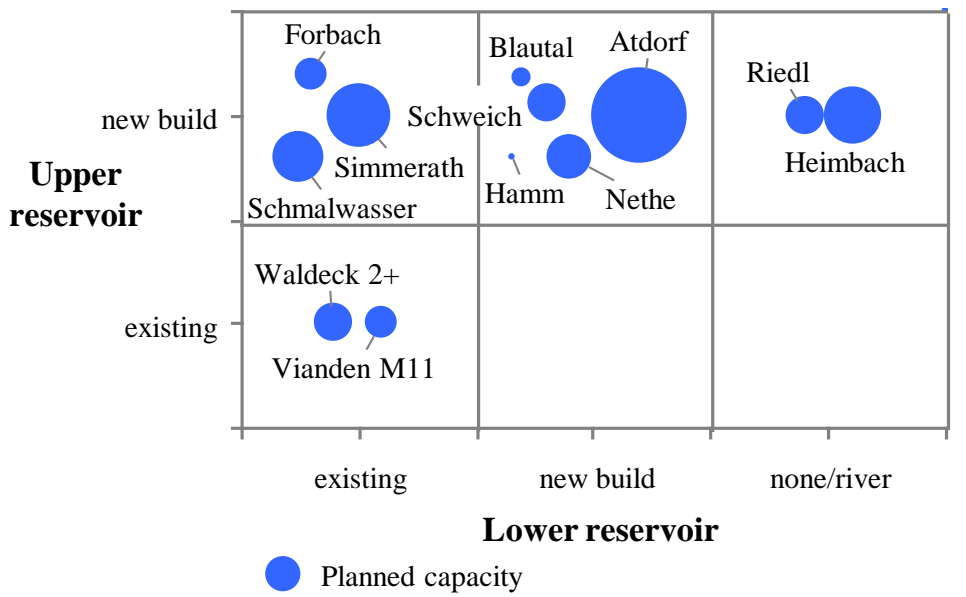

Figure 4: Basin setup of PHS projects

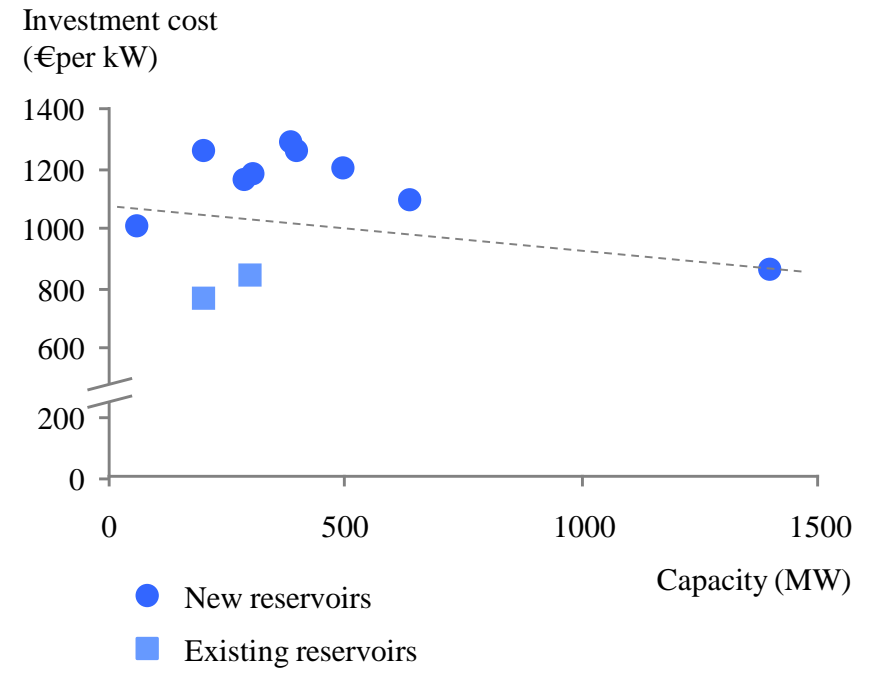

Figure 5: Announced investment costs of PHS projects 


\begin{tabular}{lccc}
\hline Model specification & $\mathrm{N}$ & coefficient & t-statistic \\
\hline All projects & 11 & -.238 & -2.48 \\
New build projects only & 9 & -.290 & -3.38 \\
New build projects only, excluding Atdorf & 8 & -.043 & -.12 \\
\hline
\end{tabular}

Table 2: Cost digression: OLS regression results

\section{Possible barriers}

Evidently, a diverse group of energy market players came to the conclusion that new PHS plants present an interesting investment opportunity. Many of the projects, however, are in an early stage and could fail to be realized for a variety of reasons. We therefore discuss possible barriers, their significance as well as approaches to overcome them.

\subsection{Profitability}

Merchant plants in the German power market are remunerated by the electricity wholesale price achieved and fees obtained for grid services, possibly supplemented by subsidies. PHS plants are no exception; thus, PHS projects have to meet the investors' profitability threshold on an individual basis. Obviously, sustainable commercial fundamentals are a conditio sine qua non - accordingly, Yang and Jackson (2011) report that besides environmental concerns, financial uncertainties were the main reason that several PHS projects have been finally dropped in the US. Concerning the situation in Germany, three revenue sources have to be regarded:

\subsubsection{Price arbitrage}

As mentioned above, the main contribution of PHS is to balance the increasingly intermittent power generation with the time-of-day-dependent load. The associated revenue source is time spread arbitrage, that depends both on the frequency and altitude of spot price variations. As an illustration, fig. 6 shows the German spot price duration curve for August 1, 2011, and the margin which could be extracted from the spot price variations (assuming that the reservoir size allows to optimally dispatch a PHS plant over the day). To estimate the revenue potential for a plant with $80 \%$ round-trip efficiency, we summarize the available margin for 2002-2010 in fig. 7, based on EEX/EPEX spot prices. On average, each MW pump/turbine capacity could have extracted $€$ 59,380 per year, although there has been strong variation over time. ${ }^{4}$ For investment costs of ca. $€ / \mathrm{kW} 1,000$, this corresponds to an internal rate of return of 5-6\% (time spread arbitrage only, before operating expenses).

Looking forward, the transformation of the generation park is likely to affect electricity spot prices. The growth of fluctuating renewable generation is a stable trend, hence the variation in residual load and spot prices will likely increase (Sensfuß et al., 2008). Besides the frequency of spot price fluctuations, though, the difference between peak and base levels is crucial for PHS profitability:

The base price level determines the cost for pumping energy. It will be available almost for free

\footnotetext{
${ }^{4}$ The margin available by optimization over the course of a day underestimates the arbitrage potential for PHS plants with very large reservoirs. The margin from using time spreads over the course of a weekwithout any reservoir size restrictions, for instance, is $€ / M W 70,000$ per year (average 2002-2010).
} 


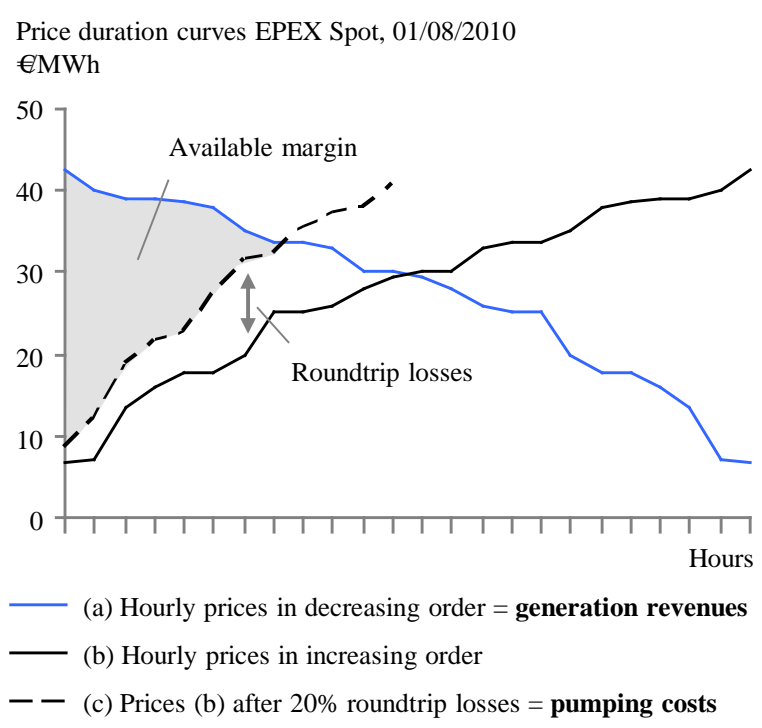

Figure 6: Illustration of time spread margin

when renewable generation exceeds the load; as Steffen and Weber (2011) point out, however, such situations rarely occur until renewable generation reaches a share of $40 \%$. Otherwise, the variable costs of base load generation have to be taken into account. Following the nuclear phase-out, this will mostly be lignite or hard coal which include $\mathrm{CO}_{2}$ emission prices as major cost component. As a result, there could be years characterized by increased $\mathrm{CO}_{2}$ prices and still limited levels of renewable generation, which turns PHS generation inefficient compared to an alternative setup of gas plants (see Steffen and Weber (2011) for a detailed discussion).

The peak price level determines the achievable revenue, with price spikes making up a considerable portion of arbitrage gains. Again, it is uncertain whether the spikes on certain days persist, as solar power capacity could have a price damping effect at noon. A further threat is rooted in the multitude of new PHS projects proposed at the same time. Naturally, the contribution margin of time spread arbitrage decreases with the storage capacity available in the market (Sioshansi, 2010). Overall, an arbitrage margin estimate based on historic time series should therefore be regarded as an indication only.

\subsubsection{Grid services}

In addition to arbitrage, reserve power and the provision of other grid services (e.g., reactive power, black start ability) are the second revenue source for PHS plants. Fig 8 shows the prices obtained in secondary reserve power auctions run by the German transmission system operators, underlining that reserve power provision can be an important contribution to earnings. ${ }^{5}$ Especially negative reserve power is currently very attractive for PHS, given its price level and the fact that it can be provided without the necessity to keep the reservoir filled.

In the future, grid services will increase in importance as the share of controllable thermal

\footnotetext{
${ }^{5}$ In Germany, reserve power is split into three layers (primary, secondary and minute reserve). PHS plants can provide all three types (Dena, 2008).
} 
Available margin from times spread arbitrage (over the course of 1 day) $€ / M W$ per year

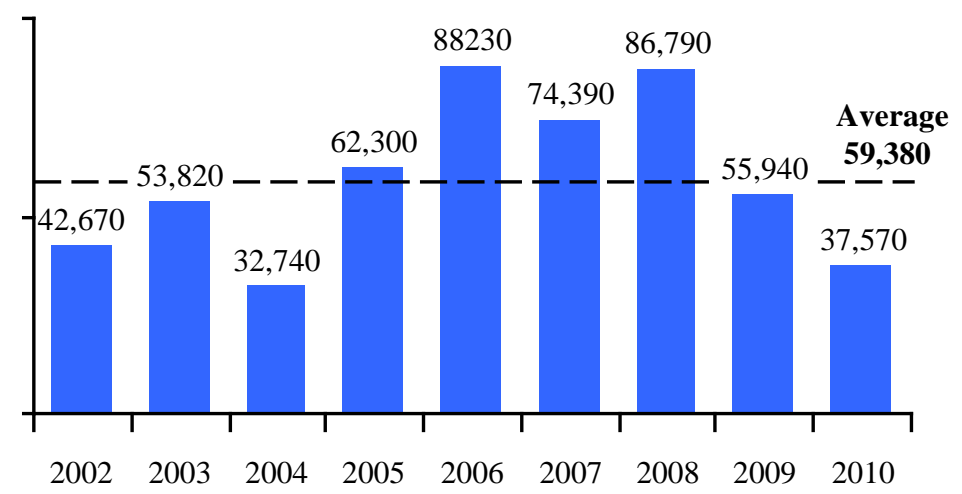

Figure 7: Estimate of time spread margin with $80 \%$ round-trip efficiency

generation decreases (Dena, 2008), which offers an upside potential for the prices of grid services that few market participants are able to offer (e.g., positive reserve power). At the same time, other services (especially negative reserve power) could also be provided by wind farms or large fleets of electric vehicles (Andersson et al., 2010), which might put the prices under pressure.

\subsubsection{Capacity subsidies}

In sum, there are considerable uncertainties concerning future electricity prices, run times and reserve power remuneration. In fact, these uncertainties are no peculiarity of PHS, but generally apply to merchant power plant projects in Germany. Starting with the decision to phase out nuclear generation, it is therefore under discussion whether flexible generation capacity complementing renewable feed-in shall be subsidized; a respective legislation is under development by the federal government (BR, 2011, No. 24). Various setups of capacity markets and other support mechanisms have been proposed (Süßenbacher et al., 2011; BET, 2011), but no decision on subsidies has been made yet. It might be the case that the profitability of PHS will eventually depend on the setup of these subsidies (BNetzA, 2011).

\subsection{Regulation}

\subsubsection{Grid fees}

Traditionally, German PHS plants have not been charged for the transmission of pumping electricity. As of January 2008, though, the regulator decided to charge grid fees for pumping electricity in the same way as for other consumption; the decision has been confirmed by the highest court in 2009 (BGH, 2009). In contrast, PHS operators argue that grid fees makes their operation inefficient, resulting in welfare losses due to the discrimination compared to other generation technologies (Krebs and Ermlich, 2008). Accordingly, a study by Dena (2008) estimates a considerable mark-up on generation costs of $2.5-2.8 \mathrm{ct} / \mathrm{kWh}$.

Economic theory states that first-best transmission prices are set according to the short-run 
Average price for secondary reserve provision $\underline{2010}$ $€ / M W$ per month

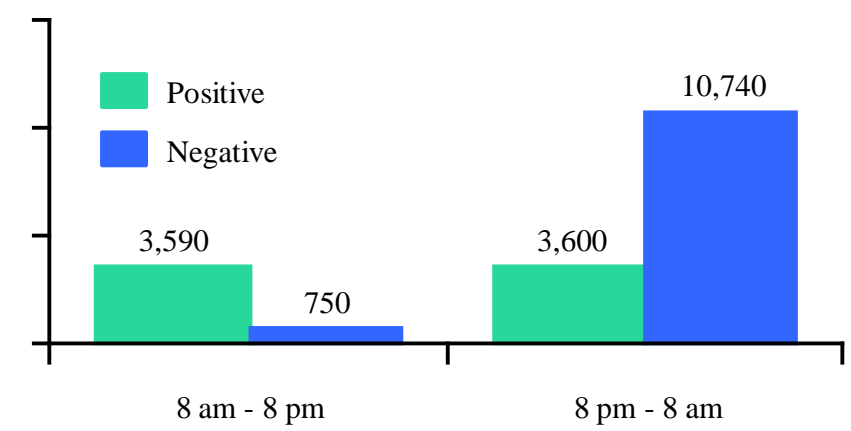

Figure 8: Prices for secondary reserve power in Germany

marginal costs caused by a grid user, typically consisting of system losses and opportunity costs for transmission constraints (Hsu, 1997; Green, 2007). While the determination of marginal costs caused by PHS plants is complex, it is obvious that pumping mostly occurs in low-load moments without transmission constraints. Marginal cost pricing, however, does not necessarily cover the fixed cost of grid operators. In this case, the second-best transmission price should be set with respect to the inverse-elasticity rule: The more elastic a demand for a product, the smaller the markup on marginal costs for that product (Crew and Kleindorfer, 1979). As demonstrated by Dena (2008), the operation of PHS plants is very elastic with respect to grid fees. A small raise in end customer grid fees, on the other hand, will not change their inelastic power demand. Consequently, an exemption of PHS from grid fees will least distort the efficient operation of the power system.

Concerning the German regulation, it has been decided in 2009 that new PHS plants will be exempt from all grid fees for 10 years (EnWG, 2009, § 118 Sec. 7); recently the exemption period was extended to 20 years $^{6}$ (GNeV, 2011). Within the legislative process, this has been considered as an incentive to pursue new PHS projects (BT-Drucksache, 2009, 2011). Consequently, grid fees should not be a barrier for the proposed new PHS plants, irrespective from the discussion concerning the grid fees charged to existing plants.

\subsubsection{Water fees}

Besides grid fees, plants using a river or lake as lower basin might be subject to water usage fees. The European water framework directive requires an adequate pricing of water usages, but allows exceptions for social, environmental or economic reasons (EC, 2000, Art. 9)-which are decided upon on a state level. Two main arguments are brought forward in favor of fees: First, costs for water usages could motivate water extractors to reduce the amount used, by substituting the production factor 'water' with other alternatives (Bergmann and Werry, 1989). In case of PHS

\footnotetext{
${ }^{6}$ The exemption is available for new plants that go online until 2026, which is beyond the planned completion date of all projects described in this paper. Extension projects (increasing the turbine or pumping capacity by at least $15 \%$ and the reservoir size by at least 5\%) qualify for a 10 year exemption from grid fees under certain conditions.
} 
operation, though, there is almost no possibility to alter the amount of water required during operation. Second, water usage fees can finance mitigation measures to compensate negative externalities from the nature intervention. As Gawel et al. (2011) argue, however, the same target is achieved more efficiently by the 'command and control' regulations within the nature conservation legislation. Additionally, any tax effect on PHS plant operators obviously conflicts with concurrent subsidies for PHS plants (like the exemption from grid fees).

As can be seen from table 3, most German states with hydro plants consequently decided to charge no water usage fees at all, exclude hydro power, or charge lump sum fees for hydro plants. An important exception is Schleswig-Holstein (location of the Geesthacht plant), where the fees introduced in 2001 reduce the profitability of PHS operation significantly, such that the plant is rarely used today (Bergedorfer Z., 2011). After years of discussion, two proposals for a reduced fee in PHS plants have been brought forward recently (SH-Drucksache, 2011a,b) - another reflection of the general political support for PHS plants. In sum, water usage fees will most likely not hamper its development.

\subsection{Nature conservation}

Given their topographic requirements, potential PHS locations are typically situated in areas little affected by civilization which often developed into habitats for nature conservation. Construction activities significantly affect these areas; permanent environmental impacts might also originate from the presence of artificial pools, infrastructure like power lines and changes in river flow patterns (Egré and Milewski, 2002).

From a legal point of view, the impact on 'Natura 2000' areas defined by the Habitats Directive (EEC, 1992) is most important for German projects. Interventions negatively affecting these areas are prohibited unless no alternative project sites exist and a overriding public interest is proven (BNatSchG, 2009; Berg, 2003, § 34). The assessment of alternative sites is a routine matter within the spatial planning procedure; the proof of an overriding public interest, in contrast, requires elaborate analysis, as the energy economic requirements apply on a national level. It is therefore worth considering whether the evaluation of overall economic advantageousness could be centralized across projects on the federal level, as it is being discussed for high voltage grid extensions (Mikesic, 2011).

Out of the current projects, the Riedl, Atdorf, Forbach and Heimbach plants are planned within or close to Natura 2000 areas. The related requirements are an essential part of the current project proposals, and will therefore unlikely be a show stopper for the majority of projects. However, environmental group actions might delay the process. ${ }^{7}$ Even if permissions are final, significant costs might occur for mitigation measures (Trussart et al., 2002) and operational restrictions, especially for the plants using a river as lower basin (Edwards et al., 1999). These costs have to be taken into account in the profitability analyses.

\footnotetext{
${ }^{7}$ This was the case for the Goldisthal plant in the 1990s. Eventually, a settlement was reached to withdraw the action in exchange for the setup of a foundation fostering environmental protection in the state (Bogenrieder, 2002).
} 


\begin{tabular}{ll}
\hline State $^{a}$ & Surface water usage fees \\
\hline BB & $0.005-0.02 € / m^{3} b(\mathrm{BbgWG}, 2004)$ \\
BW & $0.010-0.051 € / \mathrm{m}^{3} ;$ for hydro power individual fee based on capacity (WG-BW, 2010, $\left.\S 17\right)$ \\
BY & No fees \\
HE & No fees \\
MV & $0.020 € / m^{3} ;$ omitted for hydro power uses (WaEntgVO M-V, 1996, 1 Sec. 1b No. 4) \\
NI & $0.01023-0.05113 € / m^{3} ;$ omitted for hydro power uses (NWG, 2010, $\S 21$ Sec. 2 No. 7) \\
NW & $0.0035-0.045 € / m^{3} ;$ omitted for hydro power uses (WasEG, 2004, $\S 1$ Sec. 2 No. 6) \\
RP & No fees \\
SH & $0.0077 € / m^{3}(\mathrm{OWAG}, 2000)$ \\
SL & No fees \\
SN & $0.005-0.020 € / m^{3} ;$ omitted for hydro power uses (SächsWG, 2004, $\S 21$ Sec. 4 No. 3) \\
ST & No fees \\
TH & No fees \\
\hline
\end{tabular}

${ }^{a} \mathrm{BB}=$ Brandenburg, BW=Baden-Wuerttemberg, $\mathrm{BY}=$ Bavaria, $\mathrm{HE}=$ Hesse, $\mathrm{MV}=\mathrm{Mecklenburg-Western}$ Pomerania, NI= Lower Saxony, NW= North Rhine-Westphalia, RP= Rhineland-Palatinate, SH $=$ SchleswigHolstein, $\mathrm{SL}=$ Saarland, $\mathrm{SN}=$ Saxony, $\mathrm{ST}=$ Saxony-Anhalt, $\mathrm{TH}=$ Thuringia

${ }^{b}$ No PHS existent or planned in this state

Table 3: Water fees in German states (excl. city states) as of 2011

\subsection{Local acceptance}

Besides nature conservation in the legal sense, PHS structures are opposed by local residents for a variety of reasons, especially in the case of the Blautal, Riedl and Atdorf plants. Recently, resistance from local pressure groups has been the main reason for $R W E A G$ to cancel its $1.6 \mathrm{GW}$ hard coal power plant project in Ensdorf (Pahle, 2010) which demonstrates that local protests can be a serious factor in Germany. 'Not in my back yard' - type resistance occurs also for socially wanted projects, as has been extensively studied related to the sitting of wind farms (examples include van der Horst (2007); Jobert et al. (2007); Jones and Eiser (2010)).

As for the proposed PHS projects, some concerns stem from uncertainty related to the implications of water areas and dams, including bad smells, mosquito plagues, danger of bursting dams and increased earthquake risks. These worries seem to occur especially in regions where no hydro storage plant existed before; they should be addressed by transparent information to the public, possibly drawing on the experiences with well-established PHS plants in other regions (as did the representatives from the Riedl municipality who sought a dialogue with the municipality close to the Waldeck plant (FAZ, 2011)).

Besides, there are clear impairments for the local community, especially during the construction period. Classical economic theory suggests to compensate residents for the costs incurred, possibly drawing on a revealed preferences-mechanism to determine the levels of payments (O'Hare, 1977; Kleindorfer, 1986; Groothuis et al., 2008). As Frey (1997) points out, however, monetary compensation risks to crowd out civic virtue and could result in residents being even more opposed to the project. Instead, a variety of measures can help to raise local acceptance:

First, all possibilities to reduce the construction period's burdens should be evaluated. For instance, a mass-compensation approach is part of the projects Atdorf, Heimbach, Riedl and Simmerath (using the earth mass from each reservoir excavation to build the dam around it, thereby reducing the number of earth transports to and from the site); a well-planned route management is expected to keep traffic caused by the Waldeck project bearable. Second, carefullydesigned non-monetary compensations might specifically target certain disadvantages related to 
the project (Frey, 1997) - the drinking water supply system as part of the Atdorf project falls into this category. Third, it has been shown that community co-ownership raises the acceptance of wind farms (Musall and Kuik, 2011), possibly it would also improve the image of PHS projects developed by energy groups perceived as outside players. Finally, participation in the planning process might improve the evaluation of projects by residents enjoying 'procedural utility' (Stutzer and Frey, 2006); the perception of process justice and fairness has been identified as important factor raising local acceptance (Gross, 2007; Zoellner et al., 2008). In many of the proposed PHS projects the companies therefore try to involve the communities early, sometimes well before the start of the spatial planning procedure. As Zoellner et al. (2011) point out, the participation methods should thereby be well-chosen according to the needs of the specific community. For instance, a 'round-table' discussion has been initiated for Atdorf (Hustedt, 2011), and a neutral partner shall facilitate information flows concerning the Blautal project (Öko-Institut e.V., 2011).

As it is the case with many large-scale projects, there will nevertheless remain groups strictly opposing the plans; a clear commitment at the relevant political levels is therefore a crucial success factor to realize the projects in time. As the need of additional storage capacity is generally accepted by all relevant political parties in Germany, it is, however, unlikely that local interests durably hamper the growth of PHS capacity.

\section{Conclusion}

PHS is a well-established technology for large-scale storage of electricity. Its development in Germany has been largely dormant since the 1990s, which led researchers to conclude that the domestic potential is exhausted. In the light of growing intermittent renewable generation, however, a burst of new build announcement could be observed recently, with twelve projects suggesting up to 4.7 GW additional capacity during the next decade. Given the early stage of several projects, some of them might not be realized; on the other hand, additional sites are currently being evaluated.

Apparently, the hibernation of PHS development has not been due to a lack of topographically suitable locations, but rather a question of profitability. Recently, the general market conditions are changing in light of the nuclear phase-out and the transition towards green energy sources, which causes both regional and national players to re-evaluate the attractiveness of PHS. From a general point of view, the compliance with nature conservation laws as well as the handling of local resistance seem manageable for the majority of projects.

Given their high investment costs, the profitability of power plant projects is a general issue in the current German market situation. This is especially true for PHS, as the future cost of pumping electricity as well as remuneration for grid services are subject to high uncertainty. The realization of the proposed projects might therefore depend on subsidies, and it is worth evaluating the consequences of different capacity subsidy setups for storage plants.

While PHS is part of an efficient future generation portfolio, there remain limitations to its function of integrating intermittent renewable generation. Most obviously, reservoir size restrictions do not allow to absorb excess renewable generation over very long periods of time; also the severe impact on landscape will finally limit the number of new build projects. Overall, it is nevertheless a promising result that the current PHS pipeline allows to significantly increase German electricity storage capacity by means of a well-proven technology. 


\section{References}

Aachener Z., 2011a. Mega-Energiepark bewegt die Massen. Aachener Zeitung, 22/07/2011.

Aachener Z., 2011b. Trianel plant Pumpspeicherkraftwerk am Rursee. Aachener Zeitung, $08 / 07 / 2011$.

Andersson, S.-L., Elofsson, A., Galus, M., Göransson, L., Karlsson, S., Johnsson, F., Andersson, G., 2010. Plug-in hybrid electric vehicles as regulating power providers: Case studies of Sweden and Germany. Energy Policy 38, 2751-2762.

AZ Bingen, 2011. Stadtwerke setzen bei Pumpspeicherkraftwerk in Niederheimbach auf Konsens. Allgemeine Zeitung Bingen, 23/04/2011.

BbgWG, 2004. Brandenburgisches Wassergesetz. GVBl.I/05 5, 50.

Berg, G., 2003. FFH Impact Assessment and Spatial Planning Procedures. Raumforschung und Raumordnung 61, 83-97.

Bergedorfer Z., 2011. Wasserpfennig bleibt größtes Problem. Bergedorfer Zeitung, 06/06/2011.

Bergmann, E., Werry, S., 1989. Der Wasserpfennig - Konstruktion und Auswirkungen einer Wasserentnahmeabgabe. Research report No. 10201116, German Environmental Research Plan.

BET, 2011. Kapazitätsmarkt - Rahmenbedingungen, Notwendigkeit und Eckpunkte einer Ausgestaltung. Büro für Energiewirtschaft und technische Planung GmbH. Study commissioned by bne.

Beverunger R., 2011. Investor stellt sich kritischen Fragen. Beverunger Rundschau, 28/07/2011.

BGH, 2009. Beschluss vom 17. November 2009 (Pumpspeicherkraftwerke). Bundesgerichtshof, Decisions of the Federal Court of Justice EnVR 56/08.

BMWi, 2010. Energy concept for an environmentally sound, reliable and affordable energy supply. Federal Ministry for the Environment, Nature Conservation and Nuclear Safety, Federal Ministry of Economics and Technology.

BNatSchG, 2009. Gesetz über Naturschutz und Landschaftspflege (Bundesnaturschutzgesetz)/Federal Nature Conservation Act. BGBl. I, 2542.

BNetzA, 2011. Aspekte der Energiewende. Speak of the president of the Federal Network Agency Matthias Kurth, held at the EEG Conference Berlin 12/07/2011.

Bogenrieder, W., 2002. 7th Kassel Symposium on Energy Storage and Transport. ISET, Ch. Moderne Pumpspeicherkraftwerke im Gigawattbereich - Darstellung am Beispiel des PSW Goldisthal, pp. 39-59.

BR, 2011. The path to the energy of the future - reliable, affordable and environmentally sound. "Eckpunktepapier" decided by the German federal government 06/06/2011. 
BT-Drucksache, 2009. Beschlussempfehlung und Bericht des Ausschusses für Wirtschaft und Technologie zu dem Gesetzentwurf der Bundesregierung - Drucksache 16/10491 - Entwurf eines Gesetzes zur Beschleunigung des Ausbaus der Höchstspannungsnetze. Bundestags-Drucksache $16 / 12898$.

BT-Drucksache, 2011. Gesetzentwurf der Fraktionen der CDU/CSU und FDP - Entwurf eines Gesetzes zur Neuregelung energiewirtschaftsrechtlicher Vorschriften. Bundestags-Drucksache $17 / 6072$.

Crew, M. A., Kleindorfer, P. R., 1979. Public Utility Economics. St. Martin's Press.

Deane, J., O Gallachoir, B., McKeogh, E., 2010. Techno-economic review of existing and new pumped hydro energy storage plant. Renewable and Sustainable Energy Reviews 14, 1293-1302.

Dena, 2008. Untersuchung der elektrizitätswirtschaftlichen und energiepolitischen Auswirkungen der Erhebung von Netznutzungsentgelten für den Speicherstrombezug von Pumpspeicherwerken. Deutsche Energie-Agentur. Study commissioned by Vattenfall Europe Transmission GmbH.

Dena, 2010. Analyse der Notwendigkeit des Ausbaus von Pumpspeicherwerken und anderen Stromspeichern zur Integration der erneuerbaren Energien. Deutsche Energie-Agentur, study commissioned by Schluchseewerk AG.

Die Zeit, 2010a. Grün gegen Grün im Hotzenwald. 16/09/2010.

Die Zeit, 2010b. Speicherplatz für Ökostrom. 25/11/2010.

DKJ, 2010. Donaukraftwerk Jochenstein AG, Erörterungsbericht für das Raumordnungsverfahren. Regional planning meeting November 2010.

DKJ, 2011a. Donaukraftwerk Jochenstein AG freut sich über positive Landesplanerische Beurteilung. Press release 01/08/2011.

DKJ, 2011b. Donaukraftwerk Jochenstein AG informiert über Optimierungen beim Projekt Energiespeicher Riedl. Press release 25/10/2011.

EC, 2000. Directive 2000/60/EC of the European Parliament and of the Council of 23 October 2000 establishing a framework for Community action in the field of water policy. Official Journal of the European Communities L 327, 1.

EC, 2007. Technology map: A European Strategic Energy Technology Plan (SET-Plan). European Commission, SEC (2007) 1510.

Edwards, B. K., Flaim, S. J., Howitt, R. E., 1999. Optimal provision of hydroelectric power under environmental and regulatory constraints. Land Economics 75, 267-283.

EEC, 1992. Council Directive 92/43/EEC of 21 May 1992 on the conservation of natural habitats and of wild fauna and flora. Official Journal of the European Communities L 206, 7 .

Egré, D., Milewski, J. C., 2002. The diversity of hydropower projects. Energy Policy 30, 1225-1230. 
EnBW, 2010. EnBW Kraftwerke AG stellt Überlegungen zum Ausbau von Pumpspeicherkraft in Forbach vor. Press release 09/07/2010.

EnBW, 2011. EnBW Kraftwerke AG stellt Ausbaukonzept für neues Pumpspeicherkraftwerk in Forbach vor. Press release 12/10/2011.

Enervie, 2011. ENERVIE und Stadtwerke Düsseldorf kooperieren bei Projektentwicklung zum Bau von Pumpspeicherkapazitäten. press release 11/07/2011.

EnWG, 2009. Gesetz über die Elektrizitäts- und Gasversorgung (Energiewirtschaftsgesetz)/German Energy Act. BGBl. I, 2870.

E.ON Wasserkraft, 2010. E.ON plant Erweiterung des Pumpspeicherkraftwerks Waldeck 2. Press release $23 / 12 / 2010$.

E.ON Wasserkraft, 2011. E.ON informiert Einwohner der Gemeinde Edertal über geplante Erweiterung des Pumpspeicherkraftwerks Waldeck 2. press release 01/04/2011.

FAZ, 2011. Am Edersee setzt Eon auf Wasserkraft. Frankfurter Allgemeine Zeitung, 23/04/2011.

Fraunhofer IWES, 2010. Energiewirtschaftliche Bewertung von Pumpspeicherwerken und anderen Speichern im zukünftigen Stromversorgungssystem. Study commissioned by Schluchseewerk AG.

Frey, B. S., 1997. Unerwünschte Projekte, Kompensation und Akzeptanz. Analyse \& Kritik 19, $3-14$.

Gawel, E., Köck, W., Kern, K., Möckel, S., Fälsch, M., Völkner, T., Holländer, R., 2011. Weiterentwicklung von Abwasserabgabe und Wasserentnahmeentgelten zu einer umfassenden Wassernutzungsabgabe. Research report No. 370926201, German Environmental Research Plan.

Giesecke, J., Mosonyi, E., Heimerl, S., 2009. Wasserkraftanlagen: Planung, Bau und Betrieb. Springer.

GNeV, 2011. Gesetz zur Neuregelung energiewirtschaftsrechtlicher Vorschriften. BGBl. I, 1690.

Green, R., 2007. Nodal pricing of electricity: how much does it cost to get it wrong? Journal of Regulatory Economics 31, 125-149.

Groothuis, P. A., Groothuis, J. D., Whitehead, J. C., 2008. Green vs. green: Measuring the compensation required to site electrical generation windmills in a viewshed. Energy Policy 36, $1545-1550$.

Gross, C., 2007. Community perspectives of wind energy in Australia: The application of a justice and community fairness framework to increase social acceptance. Energy Policy 35, 2727-2736.

Hsu, M., 1997. An introduction to the pricing of electric power transmission. Utilities Policy 6, $257-270$.

Hustedt, M., 2011. Abschlussbericht zum Runden Tisch Pumpspeicherwerk Atdorf. 21/11/2011.

IBW, 2011. Pumpspeicherwerk Einöden. Flyer, Ingenieurbüro Kuno Weiss. 
ifo institute, University of Passau, 2010. Volkswirtschaftliche Auswirkungen des geplanten Energiespeichers Riedl. Study commissioned by Donaukraftwerk Jochstein AG.

IZH, 2011. Die Trendwende schaffen: Initiative Zukunft Harz präsentiert Ideen für die Region. Press release $24 / 03 / 2011$.

Jobert, A., Laborgne, P., Mimler, S., 2007. Local acceptance of wind energy: Factors of success identified in French and German case studies. Energy Policy 35, 2751-2760.

Jones, C. R., Eiser, J. R., 2010. Understanding 'local' opposition to wind development in the UK: How big is a backyard? Energy Policy 38, 3106-3117.

Kleindorfer, P. R., 1986. A sealed-bid auction mechanism for siting noxious facilities. American Economic Review 76, 295-299.

Öko-Institut e.V., 2011. Transparenz und Teilhabe bei den Planungen für das Pumpspeicherkraftwerk ,Blautal'. Press release 29/09/2011.

Krebs, H., Ermlich, D., 2008. Grid usage fee for pumped-storage power plants. VGB Powertech 9, $82-86$.

Mikesic, I., 2011. Das NABEG führt nur bei breitem Konsens zu einem schnellen Netzausbau. Dow Jones Energy Weekly 24, 8-11.

Musall, F. D., Kuik, O., 2011. Local acceptance of renewable energy - a case study from southeast Germany. Energy Policy 39, 3252-3260.

NWG, 2010. Niedersächsisches Wassergesetz. Nds.GVBl. 5, 64.

O'Hare, M., 1977. Not on my block you don't: Facility siting and the strategic importance of compensation. Public Policy 25, 409-458.

OWAG, 2000. Gesetz über die Erhebung einer Abgabe auf die Entnahme von Wasser aus oberirdischen Gewässern (Oberflächenwasserabgabegesetz). GVOBl.Schl.-H., 610.

Pahle, M., 2010. Germany's dash for coal: Exploring drivers and factors. Energy Policy 38, $3431-3442$.

Planungsausschuss RV Mittlerer Oberrhein, 2010. Raumordnungsverfahren Pumpspeicherkraftwerk Forbach - Vorstellung des aktuellen Planungsstands. Protocol of regional planning meeting 13/10/2010 (26/VIII).

RAG, 2010. RAG und RWE planen Windparks und Pumpspeicherkraftwerke auf Halden. Press release $23 / 11 / 2010$.

RAG, 2011. RAG Montan Immobilien und RWE Innogy informieren Anwohner über den „Energiepark Halde Sundern“. Press release 12/09/2011.

Regierungspräsidium Freiburg, 2011. Raumordnerische Beurteilung für das geplante Pumpspeicherwerk Atdorf der Schluchseewerk AG. December 2011. 
Regierungspräsidium Tübingen, 2009. Raumordnerische Beurteilung für das geplante Pumpspeicherwerk "Blautal". 30/04/2009.

Schluchseewerk, 2010. Erörterungsbericht für das Raumordnungsverfahren. Regional planning meeting April 2010.

Schomerus, T., Degenhart, H., 2011. Energiespeicherung in Bundeswasserstraßen. Solarzeitalter $2,34-38$.

SächsWG, 2004. Sächsisches Wassergesetz. SächsGVBl., 482.

Süßenbacher, W., Schwaiger, M., Stigler, H., 2011. Kapazitätsmärkte und -mechanismen im internationalen Kontext. Paper presented at IEWT 2011.

Sensfuß, F., Ragwitz, M., Genoese, M., 2008. The merit-order effect: A detailed analysis of the price effect of renewable electricity generation on spot market prices in Germany. Energy Policy $36,3086-3094$.

SEO, 2010. Newsletter No. 01 zum Ablauf der Bauarbeiten des Projektes M 11. 2010.

SEO, 2011a. Basispräsentation Maschine 11. Available at www.seo.lu/de/content/download/396/2664/version/2/file/ (download 23/06/2011).

SEO, 2011b. Newsletter No. 02 zum Ablauf der Bauarbeiten des Projektes M 11. 2011.

SGD Süd, 2011. Antragskonferenz Pumpspeicherkraftwerk Heimbach - Protocol of application conference 17/06/2011. Struktur- und Genehmigungsdirektion Süd.

SH-Drucksache, 2011a. Gesetzentwurf der Fraktion BÜNDNIS 90/DIE GRÜNEN - Entwurf eines Gesetzes zur Änderung des Gesetzes über die Erhebung einer Abgabe auf die Entnahme von Wasser aus oberirdischen Gewässern (Oberflächenwasserabgabegesetz) des Landes SchleswigHolstein. Schleswig-Holsteinischer Landtag - Drucksache 17/1777.

SH-Drucksache, 2011b. Gesetzentwurf der Fraktionen von CDU und FDP - Entwurf eines Gesetzes zur Änderung des Oberflächenwasserabgabegesetzes. Schleswig-Holsteinischer Landtag - Drucksache $17 / 1779$.

Sioshansi, R., 2010. Welfare impacts of electricity storage and the implications of ownership structure. The Energy Journal 31, 173-198.

SRU, 2011. Wege zur 100 Prozent erneuerbaren Stromversorgung - Sondergutachten. Sachverständigenrat für Umweltfragen (German Advisory Council on the Environment).

Steffen, B., Weber, C., 2011. Efficient storage capacity in power systems with thermal and renewable generation. Working paper, Univ. Duisburg-Essen 04/11.

StN, 2011. Das Wunder von Forbach ist erklärbar. Stuttgarter Nachrichten, 19/10/2011.

Stutzer, A., Frey, B. S., 2006. Political participation and procedural utility: An empirical study. European Journal of Political Research 45, 391-418. 
SW Mainz, 2011a. Stadtwerke Mainz AG, PSW Heimbach soll Energiewende forcieren. Press release $19 / 04 / 2011$.

SW Mainz, 2011b. Stadtwerke Mainz AG, Tischvorlage zur Antragskonferenz für das Raumordnungsverfahren. Regional planning meeting May 2011.

SWT, 2011a. Stadtwerke Trier GmbH, SWT plant Pumpspeicherkraftwerk. Press release $12 / 04 / 2011$.

SWT, 2011b. Stadtwerke Trier GmbH, Tischvorlage zur Antragskonferenz für das Raumordnungsverfahren. Regional planning meeting May 2010.

SWU, 2006. SWU Energie GmbH, Erläuterungsbericht für das Raumordnungsverfahren. Regional planning meeting August 2006.

SWU, 2010. Stadtwerke Ulm/Neu-Ulm GmbH, Damit erneuerbare Energien wirklich Zukunft haben. Press release 06/12/2010.

TMWAT, 2011a. Pumpspeicherkataster Thüringen. Thuringia Ministry of Economics, Labor and Technology.

TMWAT, 2011b. Trianel GmbH plant Wasserspeicherkraftwerk an der Talsperre Schmalwasser. Thuringia Ministry of Economics, Labor and Technology, press release 21/10/2011.

Trianel, 2011a. Energieversorgung von morgen - Simmerath ist dabei. Press release 08/07/2011.

Trianel, 2011b. Infoblatt Wasserspeicherkraftwerk. Handout distributed at town hall meeting Ottbergen, $13 / 09 / 2011$.

Trianel, 2011c. Stadtwerkenetzwerk plant Wasserspeicherkraftwerk an der Nethe. Press release $22 / 07 / 2011$.

Trianel, 2011d. Trianel startet Behördenverfahren für Speicherkraftwerke in NRW. Press release $15 / 09 / 2011$.

Trussart, S., Messier, D., Roquet, V., Aki, S., 2002. Hydropower projects: a review of most effective mitigation measures. Energy Policy 30, 1251-1259.

van der Horst, D., 2007. Nimby or not? exploring the relevance of location and the politics of voiced opinions in renewable energy siting controversies. Energy Policy 35, 2705-2714.

VDE, 2009. Energiespeicher in Stromversorgungssystemen mit hohem Anteil erneuerbarer Energieträger. Task Force Energiespeicher der Energietechnischen Gesellschaft im VDE.

Vennemann, P., Gruber, K.-H., Haaheim, J. U., Kunsch, A., Sistenich, H.-P., Thöni, H.-R., 2011. Pumped storage plants - status and perspectives. VGB Powertech 4, 32-38.

WaEntgVO M-V, 1996. Verordnung über das Entgelt für Wasserentnahmen (Wasserentnahmeentgeltverordnung) - Mecklenburg-Vorpommern . GVOBl. M-V, 672.

WasEG, 2004. Gesetz über die Erhebung eines Entgelts für die Entnahme von Wasser aus Gewässern - Wasserentnahmeentgeltgesetz des Landes Nordrhein-Westfalen. GV. NRW., 622. 
WAZ, 2010. RWE und RAG planen grünen Strom auf Kohlehalde. Westdeutsche Allgemeine Zeitung, 23/11/2010.

Westfalenpost, 2011. ENERVIE plant Speicherkraftwerk im Sauerland. 11/07/2011.

WG-BW, 2010. Wassergesetz für Baden-Württemberg. GBl. 13, 565.

Yang, C.-J., Jackson, R. B., 2011. Opportunities and barriers to pumped-hydro energy storage in the Unites States. Renewable and Sustainable Energy Reviews 15, 839-844.

Zoellner, J., Rau, I., Schweizer-Ries, P., 2011. Beteiligungsprozesse und Entwicklungschancen für Kommunen und Regionen. Ökologisches Wirtschaften 3, 25-27.

Zoellner, J., Schweizer-Ries, P., Wemheuer, C., 2008. Public acceptance of renewable energies: Results from case studies in Germany. Energy Policy 36, 4136-4141. 